\title{
Revitalization Of Javanese Cultural Values System: An Idea Of Character Education Based Multi-cultural
}

\author{
IM Hambali ${ }^{1}$ \\ Department of Guidance and Counseling, Faculty of Education, State University of Malang
}

\begin{abstract}
Old Javanese work of literature, which is script, is cultural inheritance contains of Javanese people living aspects in the past. Javanese work of literature mostly presents description about people living at that time, such as social order, social relationship pattern, or values supported community development around that work of literature created. Old work of literature preservation, moreover to its values, is necessary to be attempted. One of those attempts is by studying and exploring old work of literature values, with the purpose to be re-embedded in the people living. Work of literature values explored and taken by people or community may be used to maintain a region characteristic, thus foreign culture stream, which may not suitable with community values of that region, can be selected and sorted. Therefore, region culture will keep strong and the ideal values can be maintained. Value education is process of character education which has holistic goal about learners. The needs of strategy become more important and various strategy formulations needed in order to reach the goal optimally. This study is an alternative raises method in education process (in general), particularly about guiding man to be full existence organism. Thus, systematically the writer presents many examples and alternative of using.
\end{abstract}

Keywords: character education, Javanese cultural values system, multicultural

\section{INTRODUCTION}

Many characteristics of Curriculum 2013 are full of value content in which its implementation needs careful detail of guidance and counseling teachers in order to arrange a comprehensive service strategy. The prominent characteristics include: (1) Competence-based assessment, (2) Shifts from assessment through test [assessing knowledge competence only based on outcome], to the authentic assessment [assessing all competences of attitude, skills, and knowledge based on process and outcome], (3)Strengthening Criterion-Referenced Evaluation (PAP-Penilaian Acuan Patokan), which is the achievement of learning outcome based on gained score position to the ideal score (maximum), (4) The assessment not only to the Basic Competence (KD) level, but also main competence and Graduates Competence Standard (SKL), and (5) Encouraging the use of portfolio made by students as main instrument of assessment. In order to realize those targets, all education stakeholders, including counselor, must prepare strong orientation that can be implemented in each concrete program and realized in four steps (basic service, responsive, individual planning, and system supports).

Especially to the basic framework of character education implementation in which its implementation still refers to the four categories and must lead to the strong value system as well. One of the value systems that can be offered here is Javanese cultural values as foundation of supreme values rooted on Javanese culture. Various values expressed from Javanese oral literature culture, in general, can be grouped into cultural values-system orientation, where in order to group cultural values into a value system, it needs a method. Method that may be applied, according to Koentjaraningrat (1992) as follows: "I will take a framework of problem that can be implemented universally in order to analyze all cultural values systems form all cultures in the world, the framework starts to be developed by an anthropologist, Clyde Kluckhohn".

Cultural values orientation developed by

Kluckhohn (Kluckhohn, Strodtbeck, 1991) universally divides cultural values from all states in the world into five categories, based on five important problems in the human's life: 1) universal problem towards the essence of life, 2) universal problem towards the essence of work and human's efforts, 3) universal problem towards the relationship between human and nature, 4) human perception about time, and 5) universal problem towards the relationship among humans.

Framework used to analyze value orientation system in Javanese oral literature cultures is by 
using C. and F. Kluckhohn's framework that been mentioned above. The analysis result towards value orientation system in Javanese oral literature cultures explained as below.

\section{METHOD}

Method that used in this research was literature study or documentation study. Focus in this research was Javanese oral literature, which is story of folk prose. Work of literature studied in this research, mostly, was works of oral literature created and composed by poets in the 18th and 19th Century, by consideration that those centuries were awakening centuries of Javanese oral literature development. Even, Javanese oral literature achieved its glory of golden age, particularly under the government of sinuwun Paku Buwana IV in Surakarta.

Data in this research was citation sentences from traditional expression, riddle, folk poem, and story of folk prose. Data that used in this research obtained from literature sources, books contained script of Javanese oral literature and/or its translation as well as research and study results. Data of citation sentences from script of Javanese oral literature collected through many stages, identification to the whole scripts of oral literature that been established as data source. The collected data of Javanese oral literature then analyzed by its validity. Data validity test intended to assure that the data is truly appropriate to its original version. Data test conducted by using source triangulation technique, which is the attempt to match the truth of oral literature contained in the studied book with other sources. Data of traditional expression matched between two studied books and compared between one to another. Data of poem and folk story (folklore) matched by book with the title of "Nilai Budaya Sastra Lisan Jawa (Cultural Values of Javanese Oral Literature)".

As with the research goal, which was to explore values contained in Javanese oral literature, it was made as formulation material towards education, guidance and counseling theory development based on Javanese oral literature culture. Analysis method that used in this research was Content Analysis with the steps as follow: (1) data of citation from script of Javanese oral literature translated by using translations of Indonesian and Regional Literature Book Publishing, Ministry of Education and Culture, Jakarta project team. The
Javanese oral literature translation then studied by using books of research result, studied from the thought of experts as informant, thus it could reveal cultural values in Javanese oral literature and probably about its utilization towards education, guidance and counseling setting, (2) Cultural values of Javanese oral literature that studied in the first step then classified by using basic orientation framework in human's life developed by Kluckhohn, which is related to the essence of life, the essence of work, time orientation, the essence of relationship among humans, and the essence of relationship between human and nature, (3) Javanese people values that obtained from Javanese oral literature then classified into the second step and adapted by theory and approach in counseling.

Values revealed from traditional expression stated that Javanese people believe in themselves to have potentials to do something in order to fulfill their needs. By this basic value, it can be developed by a technique in order to assist humans in developing their potentials optimally.

\section{RESULTS}

\subsection{Problem Towards The Essence of Human's Life}

There is a difference among Javanese people in viewing the essence of life. One of them are the understanding of Javanese people in viewing life as bad thing, full of misery and affliction. "Cultures affected by certain belief, for example, can be percepted to concept life as bad thing". The understanding towards the essence of life which full of misery mostly developed around rural people. However, illiteracy Javanese people, who are very poor, generally will accept their condition as fate. They, basically, view this life as set of events which full of misery that must be passed patiently.

While, other concept, different from the first, included into santri (adherent of Islam) criteria (mostly stay in the coastal area or in the city). They view the essence of life as gift from God that must be kept. Due to this life, actually, is borrowed thing (barang sanggaman). Like a borrower, when the time comes, then it must be returned to the Only One God. In the translation of folk poem script citation of Dumbasawala (in Mijil 44th, 45th, and 46th verse), it stated that all we have are borrowed thing including our soul.

Are you not realize, why you avoid the existence of God, isn't it because of God this 
life occurred, actually humans even do not owe life and death, except all are God as the owner.

Your life attitude and behavior, even this life, anything happened to you, all are the will of God, do not you ever feel that you have it all, yours, actually only borrowed thing (barang senggama).

Borrow as God's permit, your right is only to use that borrowed thing,

Your duty as human only do the best (ikhtiar), wisdom in order to guide your wills, life safely and peaceful.

The essence of life analogized as borrowed thing that must be kept, do not make it stained from bad actions. In the translation of script citation of Suluk Seh Siti Jenar, it stated about human's duty to keep the life.

New belief likes the desired fate, as spiritual knowledge which becomes clothes over the knowledge about God, absolutely, it is really difficult, due to five good (sacred) wisdoms, all related to the this whole body, both outside and inside, there is nothing can be brought for the hereafter. Although all cannot be stained, dirty, even poisoned.

Other tems that used by Javanese people to accommodate their belief about life, mostly analogized that life is only temporary place to drink. "Gesang punika naming mampir ngombe", Koentjaraningrat (1984: 403) stated that "according to the spiritual mystical knowledge of Javanese people, human's life is part of universe as a whole and only truly small part of the relationship between eternal universe, where humans as if they only stop for a while to drink". In never ending trip to look for final goal, which is to be united with The Creator. Or in other words, it is also frequently stated by Javanese people that this life likes one goes to the market, only for a while and back to home soon. "Gesang punika kados tiyang lumaku menyang pasar". This kind of expression also frequently used by Javanese people.

The santri (adherent of Islam) views this temporary life by pointing on hadith of Rosulullah as follows:

The world has no meaning on me and I am not in this world except such as a wanderer takes shelter under the tree in order to take a rest for a while. Then the three will be left immediately. (Al Hadits)

This temporal life is place to collect supplies for preparation to the hereafter. In collecting life supplies, it cannot be separated from obstacles as a test in human's life. This test can be bliss or misery. "This world is only house of test while the hereafter is eternal place that absolutely destinated by every human" (M.Mutawalli Asyya'rawi, 1996:68). Translation of script citation of Babad Jaka Tingkir, BabadPajang described about one that is tested by the bliss of life such as position and wealth.

"For them who sit on the chair, abundant of wealth, have beautiful house, they feel very happy. Do not you know that all people in this world finally will be extinct come to the ground. However, human loves to be arrogant. How pity those actions, they do not know that themselves as if a carcass. However, why human always feel like they are noble"

In facing test in this life, humans need to be careful and wise. Never forget about where they come from when they are in the top of glory and never give up in facing misery. Bliss and misery in life come alternately for all people. Javanese people stated that this life likes rounded wheel (cakra manggilingan). Concept of fate for Javanese people is direction to accept all tests in life. The same thing that fate is final conclusion from efforts and attempts (ikhtiar) that been conducted. People have to try as much as possible in order to get better condition. The attitude to accept fate means as mentioned by de Jong (1976:19): "For Javanese people, accept (narima) in fact or fate can meet the duty carefully". Other definition from effort (ikhtiar) is all attempts and tests that must be passed in order to cope with life difficulty.

The effort (ikhtiar) believed as mediator in order to make God grants their wish to be real. Because the determinant whether one's effort is success or failed is the power of God, such represented in the citation of traditional expression as follows:

"Pangeran Kuasa Menunggu Bisa"

God has power over human

Although this life is full of test, however, humans may try their best to be good and reach the happiness.

\subsection{The Essence of Work}

Simply, Javanese people have the understanding about work. In essence, work functions as goal to survive in life. Javanese people in rural area is an example that we can find today. 
Koentjaraningrat (1984:437) stated that "in general, rural people rarely have speculation about the essence of their work, about job, and the meaning of their effort, except believe that they must always do the best and work hard".

Life for Javanese people in rural area seen as very simple thing. In this life, they only need house, foods, and clothes (papan, pangan, dan sandang). All their best efforts only to fulfill those three things above. Affected by monotonous life in rural area (village) (work at the day and sleep at night), rural people never think about position, occupation, or other life luxuries, thus in rural area, life ambition and competition go naturally. Rural people frequently state that their efforts only to get rice (ngupaya upa). Their hard work represented on traditional expression below:

"Direwangi Adus kringet"

Accompanied by full of sweat

Part of educated rural people able to give further explanation about the essence of work, not merely related to the duty in fulfilling main needs, but more than that, work is facility to achieve the more priority goal of life. "They relate problem of final goal and human's effort fulfillment to the new concept that they will gain in the hereafter. Theme about this reward concept is in line with Islamic religion" Koentjaraningrat (1984:437).

Further understanding about work based on a belief that only them who work and do the effort that will gain reward, as well as they believe about natural law that every human action will have effect, such represented on traditional expression below:

Ngunduh".

"Sapa nggawe nganggo, sapa nandur

Who create will use, who cultivate will harvest

Work as a duty related to the reward can be read in the translation of folk poem citation of Wulang Reh (in Asmaradhana, 1st verse)

Let us obey the syaria rules, physically and spiritually, also pray (sholat) five times, cannot be ignored, who ignore the rule will be barren, if still love to serve to the king

Javanese people, in realizing the work, also conducted by mastering themselves and their thought, with the aim to reach closeness to God. Then pray to God in order to make their wish comes true. The work that realized through praying can be seen in the script citation of Babad jaka Tingkir: or Babad Pajang. The translation as follows:

"Then the woods created in long and rounded order piles. The rope strongly binds over the size of saka guru that becomes the duty to be completed in that day. There is no difference, the long shape already likes a pole, soon Seh Malaya prays begging for God's bless, wish that the desire will be granted

Such as slightly educated rural people, priyayi (the upper class people) also related the final goal and their work with reward. However, priyayi mostly live in the city were they must live with high competition. The needs that must be fulfilled not only main needs.

Koentjaraningrat (1984:438) stated "the desire of Javanese priyayi about position and power over physical symbols of wealth as well as tight relationship with superior and high positioned people". This kind of desires described in the translation of folk poem script citation of Dumbasawala (in Kinanthi, 20th, 21st, 22nd verse) as below:

If your feeling already silent, the silence combined to the magical things, moreover God's gift comes to you, it is not impossible for you in wise level, you will recognize all omnipotence exposed in the world, is it suitable that you are named as "mantra agung".

If you want yourself as "wirayawan" ("wirayawan" means noble, brave, or hold power), reach the glory on God's bless, you will be safe, however reach it by concern, in your sleep you will always obey (tawakal), sleep only as "soul" rest, the eyes open look at the real condition

Few or small part of priyayi, despite relate their work to the reward or karma comes from Hindu and Buddha religion, the work also related to the concrete idea as final goal of their work and that is considered as reward. This type of belief developed by priyayi (the upper class people) who follow spiritual philosophy. These concrete goals are position, wealth, power, and close relationship to the superiors and high positioned people. These goals represented in the translation of folk poem script citation of Wulang Dalem Paku buwono IX (in Asmaradhana, 12nd and 13th verse).

Request to God, is the main guidance, to the God's will, keep loving it, the duty to be servant, replaced to be the master

In order in the future, all your generations, remembered by the superior, as generation that keep the loyalty, to the superior with affection, the needs of live people, only sacrifice will be left.

In general, there is similarity of understanding about work between slightly educated people in rural area and priyayi, which is relating final goal and their work with reward, although, few of priyayi consider that the meaning of reward is concrete such as position, power, and wealth. They may be followed spiritual philosophy. 


\subsection{The Relationship between Human and Nature}

Javanese people ethic about passively accept (narimo) and concept of fate affected to the Javanese people view about the essence of relationship with nature. People in rural area in which their daily living mostly related to the nature and all natural powers, then they learn to adjust themselves with nature. It is conducted, particularly, due to they have no ability to analyze natural power, although Javanese people view nature and all the powers with narimo ethic and concept of fate, they do not give up easily to the fate. There are efforts to be able in affecting nature. [1] explained "then, if one wants to live without that disturbance, he/she must do something to affect universe such as by concerning, fasting, prohibiting to do something as well as to eat certain foods". These concerning values such expressed in the translation of folklore script citation of Serat Cemporet as follows:

"Oh the king, do not you depress about bad fate of your son, accept it as fate. There will be a time through the meeting of true mate between son of king Pegelen and daughter of king Jepara that been fated as the marriage partner. They meet in Medangsewu through the power of God, now give command to both of them to meditate or concern by self-undercover for a while".

Other effort conducted by Javanese people in order to be free from bad natural powers is by ngruwat ceremony. "Ruwatan has meaning to be free from stain, free from contemptible, destroy the disasters" (Subalidinata, 1985: 155) or, other definition stated by Sulardjo Pontjosutirto (1985:109) " the implementation of ngruwat ceremony or called as ruwatan means free or to be free, which is free from God's punishment or bad curse". Javanese people related one's safety with kala. Kala is giant preys human and humans that included into kala's food are them who called as Anak Sukra as below:

Anak ontang-anting :single male child

Anak unting-unting :single male daughter

Anak kedhana-kedhini : child that survives among all brothers and sister that passed away

Anak kembang sepasang : two children, both are female

Anak uger-uger lawang : two children, both are male
Anak gondhang kasih : two children, one is black and other is white

In order to avoid kala (bathara kala), "parents should make them free by tolak, ngruwat or ngrucat ceremony" (Bambang Suwondo, 1977: 146-147).

Although humans always try to keep harmony with nature, however, facing natural powers such as flood that loses everything, earthquake that destroys anything, and volcano eruption that takes many souls, they face it with attitude of accepting fate and only with small efforts. However, they still have duty to preserve earth's beautifulness (memayu ayuningbawana).

Celebration (selamatan) ceremonies usually performed by Javanese people. [1] divides the ceremony as follows: (1) celebration in order to celebrate one's life cycle such as seventh month pregnant, birth, first hair cutting ceremony, touch the ground ceremony, ears pierced ceremony, circumcision, death, and also moments after death; (2) celebration related to clean the village, agricultural land processing, and after rice harvest; (3) Celebration related to the big days and big months of Islam; and (4) celebration in uncertain moments related to the phenomena such as far journey, staying at new house, avoiding the danger, and so forth.

Human defenselessness is to the certainty which cannot be predicted and anticipated as well as human has no power to avoid it such as death which packaged by Javanese pople in traditional expression as follows:

"Digedhongana, Dikuncenana Wong Mati Mangsa Wurunga"

Prisoned, locked, the death will surely come

Even human inability to prosecute for justice or truth mostly returned to the natural power to handle.

This type of defenselessness is defenselessness accompanied by expectation and wish about other certainty. This type of belief can be found in the traditional expression citation as follows:

"Becik Ketitik Ala Ketara"

Goodness will be revealed, badness will be noticed

Javanese people believe that all injustice cases and arbitrary actions, indeed, will have limit, and finally all will get revenge equal with the actions. 


\subsection{Javanese People Perception about Time}

Javanese people, in general, and particularly people in rural are create time orientation to the future times/periods. The expectation about better life becomes the spirit of Javanese people in facing the future. Belief about the coming of ratu adil becomes basic of their expectation, that will bring better life, more fair, more prosperous, in which becomes idea and goal of national development until today. The description about welfare in this life such in the traditional expression below:

"Gemah Ripah Loh Jinawe Karta Raharjo"

Peace, prosperous, welfare, and well-ordered

Javanese people spirit to get better life in the future related to the forecast of keratin poet, Ranggawarsito included in the script citation of Sabdatama (in Gambuh, 16th verse) as follows: (in the glory period) the feeling goes through (heartstrings), distressed by certain time, (over) the power of Almighty God, (which is) fact of wahyu (vision from God to man), keep in preservation cannot be destroyed (fell down).

The belief about better future becomes spirit of their work hard. Wahyu is not passed in vain, when there is a time then there is an opportunity in their effort to face the coming of prosperity. Time becomes very important and meaningful due to it is related to the gained livelihood by someone such in the traditional expression below:

"Ana Dhina Ana Upa"

There is a day, there is a livelihood

Mystical and spiritual values affected to the view of Javanese people about time, thus their perception about time becomes very sharp and even has complex methods. All one living activities related to the very tight time. "Generally, their plans, decisions, and behavioral orientations showed to the perception of present time" (Koentjaraningrat, 1984: 439).

Javanese people, in determining journey moment (lelungan) or move to a new house (boyongan) relate to the calculation of naga tahun. In the month of sura, sapar, mulud (May, June, July), Javanese people are prohibited to take journey to the east (wetan) or south (kidul). Or in doing business, Javanese people use naga pasaran, which is Monday has pasaran in the east (wetan) area, Tuesday in the south (kidul), and so forth (cited from Soemadidjojo Mahadewa, 1965).

Javanese people also know about fortunate times for business, taking journey, and planting or cultivation. As well, Javanese people believe in certain times that prohibited to do business. Those times are na'as (bad) times which will result in failed or bad luck if it is violated. Na'as times (na'as day, na'as month, na'as year), if it is related to the child's birth, then Javanese people believe that child born on na'as time will be sick frequently (Soemododjojo Mahadewa, 1965). The belief of complicated time calculation above developed, particularly, around Javanese people with kejawen concept in which it is different with people in rural area. Perception of priyayi in viewing time mostly oriented to the past. Priyayi that still in the noble lineage (blue blooded) always believe in greatness and glory of their ancestor. They perceive that they need to keep traditional values related to the palace traditions to legalize their existence in the society. Priyayi living is more monotonous than Javanese people in general. Priyayi living has not much variations, working in the office from day to day, their nostalgic moment to the heirlooms, their activities to do many complicated rituals related to the heirloom maintenance, and their preference to investigate about family tree, heroic story, mythology, old poet works, and so forth are characteristics of traditional priyayi life style that give meaning to their life. It can be seen in the society that they are very proud if they have noble or heroes' lineage; for example, Javanese people are willing to add title of raden/roro as noble mark which placed in the front of their name.

\subsection{The Relationship among Humans}

The relationship of Javanese people among others has two ways pattern, collateral (horizontal) oriented pattern, which is dependence sense to others (mutual assistance spirit) and vertical oriented pattern, which is dependence sense to the superior figures.

Relationship pattern that oriented to the horizontal relationship created due to awareness that human cannot live alone, especially in fulfilling their needs, people need other's helps. Anything that can be used to maintain the relationship among others kept by respecting each other and other polite attitudes.

"Very prominent aspect in this way of thinking is feeling that one is not alone in this world and that one always expect assistance from others, especially their relations and as the opposite also expect the same thing from them" (Konetjaraningrat, 1984: 440). 
This definition explains interdependence relationship among others (horizontal relationship). Horizontal relationship among Javanese people and their efforts to maintain the relationship can be read in the translation of folk poem script of Dumbasawala (in Pucung, 30th, 31st, and 32nd verse) below:

Virtuous people always imitate main action, being good to others, as flower fragrant of its language.

Good language is very impressing to the heart, far to reach the feeling, strongly adhered to the bones, to the death good character will be remembered.

Even the generation still affected by the goodness feeling happiness and authority, misery for them who do bad things, many examples of misery exposed.

Or it also can be read in the translation of folk poem script citation of Dumbasawala (in Sinom, 3rd, 4th verse) below:

Respect others, like you respect to yourself, your heart as measurement, do not you hurt other's heart, make envy and jealous (greedy) character away from you, however, you must know their intention.

About attitude and well behaved, do not ever forget it, that human is complex and complicated, for that reason be careful in every action, uphold main values of yourself, make bad actions (contemptible, blackened, evil) away, moreover do the bad things to the colleague.

Translation of script citation above describes how important well behaved, friendly, and good attitude is, as something that must be conducted in order to maintain harmonic relationship in social living. Hildret Geertz (1985:151) stated that: "Unity value (in Javanese expression named harmony), is determination to maintain harmonic social statement by reducing social and personal conflict as much as possible publicly in any formations". One's success in social relationship assessed by his/her ability to adapt with environmental around, particularly new environment. Social relationship values of Javanese people includes in the traditional expression below: Angger Agi Dudu Aja Kaya Dadi, Angger Agi Dadi Aja Kaya Dudu.

If you are not do not pretend to be, if you are to be do not pretend that you are not

Social harmony realization intended that with the harmonic relationship they will be able to help each other, such mentioned by Suseno (1988:39): "Harmony means harmonic condition, without any competition and conflict, united into intention to help each other".

In general, individualism values have not much developed in Javanese people "Privacy in Javanese people has no high value. What is valued? Indeed, life in a group with communal, harmonic, friendly, and kinship character. Group member (neighbor) that live alone, does not want to create relationship or come to others will have name bandied about, even can be isolated" (Munandir, 1989: 14)

The second relationship pattern is oriented to the vertical relationship. This type of relationship mostly developed in priyayi group. As with people in rural area, there is also dependence characteristic to others, parents, seniors, even to superiors. Related to the vertical relationship pattern around priyayi (the upper class) group, Koentjaraningrat (1984: 422) stated that "In opposite, their manner heavily oriented to the vertical values, and noticed with their attitude that heavily depend on, trust, and interested to the seniors or superiors, thus most of times they have no interest to do self-responsibility". C. Geertz (1983: 153-160) described that "Interaction in the Javanese people goes through two principles, "bekti" (devotion) of respect and harmony". Devotion also means that "Word of devotion ("bekti") means as obey and respect statement, or loyalty" (Moeliono, 1989: 71). In the translation of script citation of Babad Sultan Agung stated that:

People who see the departure of Wiraguna are astonished, however they already heard that Wiraguna delegated by Sultan Agung to the northwest, journey direction of Wiraguna. He must go through jungle, canyon, and mountain of Parang Sirung by paying no attention on dangerous things in his journey. The goal is conducting the order of Sultan Agung to go to Dieng mountain.

Vertical relationship pattern which prioritizing on manut (obedient) to the elders or superiors cannot be separated from parenting pattern in raising the children. Munandir (1989:14) stated that "Parenting pattern in home, teaches about child's behavior to be turut (obedient), always taren (ask for permission) to the parents". Or parenting pattern conducted by priyayi family, according to Koentjaraningrat (1984: 242- 243): "since early, a child has known about hierarchy based on age among siblings, the child also knows that he/she must shows respect to the father as he/she is getting older". 
Vertical relationship in Javanese people makes them always need to ask for blessing ("restu") from parents or elders (ruler, leader). In the case of "restu", Moenandir (1989:15) stated that "blessing ("restu") also asked for important events such as to take a journey, rice planting time, wedding, move to a new house". Vertical mentality affected to the weak character to be independent and will have no feeling to be responsible about the actions. All will be returned to parents or elders (ruler, leader). The same thing for manut (obedient) characteristic that always be embedded to their children (priyayi) due to the belief that manut (obedient) is key of success.

\subsection{Conditions for the Change}

Counseling, based on Javanese cultural values, is assistance process which emphasized on personal growth, developing the desired behavior according to the accepted patterns in order to have ideal live as the goal of social groups.

Counseling based on Javanese cultural values not only tried to encourage individuals who have problems to be solved and released; however, it also tried to encourage individuals to be main human (personal) as with the idea of Javanese people which actually also becomes the goal of life for Javanese people in general (not only them with problems). In order to realize the idea, indeed, it needs counseling techniques related to the developed assistance process.

The explanation that human's attitude developed since the individual was born, or even before the birth, then it can be considered that Javanese people use stimuli and response to create children's attitude. Thus, the development of deviance attitude may be caused by less or too much stimuli or response which not appropriate to the delivered stimuli. It also can be sourced from initiative development system of "Umbar", in which it asists to develop free, over children's attitude, even children failed in adaptation to the environmental around make the children rigid.

Analysis to the attitude development due to failure in initial development step results in the needs to change the developed attitude in order to create attitude which suitable to the Javanese people values and norms.

\subsection{The Change Steps and Techniques}

The change steps and techniques that may be developed to assist individual changes as follow:

\subsubsection{Total Self-Mastery (Psychological and Physical)}

Before counselor invites clients to look for alternatives of problem solution faced by clients and make plans of life development, the first step that must be conducted by counselor is directing clients in order to realize their problems, or neutralizing/balancing client's condition if they cannot control themselves such as in sad, angry, confuse, depressed by their feeling or complicated mind. Javanese people always emphasize on Eling to people who are in those conditions. Eling means remember where it is important due to it is related to the self-awareness or the main part is aware about themselves in Javanese philosophy. (Soebagio Sastro-wardoyo, 1985: 696).

Counselor invites clients to Eling (remember or aware) as bridge to correlate experience in the past and present time, thus clients will be aware about the essence of correlated and sustainable selfexperience, I am who fail now, then next year will be I am who gain prosperity.

According to (Soebagio Sastrowardoyo, 1985: 700), this Eling step can be achieved through spiritual preparation and vision called Neng (abbreviation of Meneng) means he/she and Ning (abbreviation of Wening) means clear. These methods, by Javanese people, defined as meditation, while by santri group (adherent of Islam), meditation means Tafakkur, which is contemplating and thinking about all phenomena.

In order to reach Eling (awareness) step, counselor invites clients to meditate/tafakur, by giving explanation about the intention and goal. Counselor invites clients to pray for a while and in the beginning counselor uses term of Eling to the time when it is really silence until its adequate time.

\subsubsection{Logic Sharpening to solve problem and make life plan}

After clients able to control themselves and gain their awareness about present experiences which related to the past experiences, then counselor asks clients to make alternative of problem solution and make life plan that will be lived with logical mind, thus clients can be wise as with factual situation/condition.

In order to make clients able to choose alternative of problem solution, it can be performed through these techniques:

a) Empathy 
Empaty is counselor's ability to communicate to clients that the counselor understands about what is client talking about. High empathy to the clients will make clients able to gain deeper selfunderstanding through the relationship with counselor. This technique used as bridge between the first and second step.

Illustration

Counselor uses illustration to clarify conversation materials which in line with logical minds

b) Systematic desensitization

In this technique, counselor creates potential condition which is reason of irrational feelings or thinking. For example, clients with dark place phobia, then counselor can create a condition which goes through dark corridors accompanied with certain stimuli (there is nothing there), thus clients will only relax to go through the darkness.

\section{c) Self-control}

This technique used to identify client's behavior by arousing and developing self-control. The core of this technique is how clients can control themselves based on logical thoughts.

d) Reinforcement

Is technique used to encourage clients toward more logical behavior by giving reward or punishment.

\section{e) Confrontation}

Counselor uses confrontation to express thoughts that are not in line with the desired goal and behavior. Confrontation can be viewed as effort of giving attention and should be performed appropriately in order to make them realize that their unawareness will hamper their strength.

Based on analysis result to the Javanese oral literature cultures, then the research which used literature sources of books contained Javanese oral literature cultures as data can be concluded as follows: (1) Oral literature cultures developed in Javanese people can be made as guidance in order to know and understand about values that believed and make as guidance in daily living of Javanese people. it can be understood because oral literature culture is facility to develop and embed ideal values that believed and make as guidance of Javanese people in the past, thus Javanese oral literature also represents people life in the past that full of ideal values; (2) The result of study to the Javanese oral literature cultures can reveal Javanese people values including: 1) religious values, 2) firmness values, 3) nature related values, 4) virtuous values, 5) work hard values, 6) sacrifice values, 7) discipline values, 8) carefulness values, 9) peaceful values, 10) awareness values, 11) attention values, 12) obedient values, 13) harmonic values, and 14) time related values. Those values keep embedded and developed until this time. It can be found that today, most of Javanese people, try to make all their attitudes and behaviors always in line with the believed values above; (3) Cultural values expressed from Javanese oral literature cultures classified as with basic orientation to the general cultural values. This classification conducted by using framework developed by C. and F. Klukhon (1961), which universally divides cultural values from all states in the world into five categories, based on five important problems in the human's life. Thus, it can be known basic orientation of Javanese people in viewing five important problems in life.

Javanese people view about life, few of them view that this life as bad thing. Concept of life is bad thing may be affected by Buddha religion. However, in general, Javanese people view life as good thing. It is due to the belief that as long as there is a life, people will have opportunity to show their ability in order to be free from badness of life. Actually, badness in life is a test, thus humans must be patience (ikhtiar) in order to be free from badness of life, to get better life.

This view, mainly concepted by Javanese people that included into polarization of santri group and Javanese people in general. Simply, Javanese people have understanding that teh essence of work is to survive. This understanding mainly developed towards people in rural area that less educated. Less educated people in rural area only work due to they believe that live people must try their best and be patience in order to survive, while slightly educated people in rural area give understanding to the essence of work further, which relate their work to the final goal of reward, and small part educated Javanese people understand that the essence of work is to add works.

Javanese people in rural area, in all their attitudes to fulfill their daily needs, mostly related to nature and natural powers. They live by adjusting themselves to nature and accept the effect of natural powers that they suffer. It is implemented, mainly, due to they have no ability to analyze natural powers. Although natural symptoms such as flood that loses everything and volcano eruption that takes many souls, they face it with attitude of accepting fate; however, they also try to anticipate although with less efforts. 
In general, Javanese people perform time orientation to the future accompanied with expectations and wishes about better future, while

Javanese people with noble lineage and priyayi (the upper class) still involved in traditional values, they have time orientation to the past by preserving their ancestor traditions

The essence of relationship between Javanese people and others consist of two patterns, collateral (horizontal) orientation, which is dependence sense to others. This horizontal relationship created due to Javanese people need to maintain social values such as well behave, friendly, and mutual assistance. It is due to those values are facility to create and maintain relationship with others. The second pattern is vertical orientation, which is dependence sense to seniors, leaders, high positioned people, both formal and informal.

Guidance and counseling practice which created from West can be adapted by values developed in Javanese people, thus it will be obtained formulation material to arrange counseling theories based on Javanese cultural values and humanity assistance based on religious and traditional values in Indonesia in which those two aspects can be met.

Guidance and counseling with set of scientific theory and technique, which becomes its characteristic, will be more complete if it is combined with traditional assistance practices related to the mystical values and refers to the ideal values uphold in Javanese people. Thus, it can determine how Javanese people view the essence of human, personality theory about the essence of human attitude, either deviance or normal. It also can be found that Javanese people parenting heavily affected to the development of children's attitude.

Moreover, parenting becomes basic or foundation about how Javanese people understand this life, understand the essence of time, work, relationship with nature, and relationship with others. Parenting and basic orientation in Javanese people life can be made as reference and consideration materials to implement counseling techniques.

Ethic strength of "Eling" (aware) which generally used by Javanese people to return someone's awareness about themselves and problems they have, developed by counseling techniques in order to obtain techniques to change attitude scientifically with the touch of Javanese mystical values.

\section{SUGGESTIONS}

Based on study result, it can be known that in order to arrange counseling theory based on Javanese cultural values and the theory implementation, it needs further development attempt by conducting further research, either individual or institutional research. Therefore, it may be considered many suggestions as follow:

Rich values contained in Javanese oral literature still cannot be revealed completely. In order to reveal it completely, it needs to be focused on one element of Javanese oral literature in which it should be determined by one element that will be studied in-depth, about folk poem, folk prose, or traditional expression. It is expected that by focusing on values contained in one element of Javanese oral literature, it can be conducted by complete and indepth research.

Formulation material of counseling theory based on Javanese cultural values can be created by inserting local values to the counseling technique and theory. Various practices of traditional assistance in Java need to be studied in-depth which then changed into practice of scientific-traditional assistance or adopted to be one practice to change behavior in counseling process as a whole.

Eling as the highest ethic in history of Javanese people has very important function in returning one's awareness. Eling which related to the mystical values believed will be able to bring changes in behavior. Process to gain Eling as technique to return one's awareness needs to be developed, thus Eling as Javanese ethic considered as high valued, can be functioned as media to change behavior on its own from the whole counseling process. For example, someone who suffered by fire disaster that destroys his/her life, sadness and misery that he/she faced may be reduced by asking that one to Eling, Eling that this life is a place of test, this life is transient and uneternal, then all in this life finally will be returned to the Almighty God and people who able to pass the test patiently then they will achieve happiness in the hereafter.

The understanding about the essence of human according Javanese people can be made as formulation material to develop counseling theory based on Javanese cultural values. For example, human, according to the view of Javanese people, is creature that believes in God. Then, in implementing counseling, clients invited to be closer to God and return the solution of their problems to God, indeed after they tried their best. Therefore, whatever the 
result from their efforts will be accepted due to all the results related to the power of God.

The implementation of counseling theory based on Javanese cultural values applied, particularly, to the problems faced by clients related to the believed and ideal values. For instance, Javanese people have too much reluctant feeling to others. Then, clients asked to understand by confronting equality concept in life among humans, which is also Javanese people value.

The implementation of counseling theory based on Javanese cultural values is for clients of Javanese people and raised in Javanese cultures, or clients who are not Javanese but raised in Javanese cultures such as Arabian, Indian, and Chinese that born and raised in Java. The implementation of counseling theory based on Javanese cultural values is not limited by place, may be in Java or outside Java with notification tat clients and their problems related to the Javanese cultural values and counselor should not be Javanese people, in this case, the more important thing for clients is counselor understands about Javanese values and cultures.

\section{REFERENCES}

[1] Koentjoroningrat.1976.Manusia dan Kebudayaan di Indonesia.Jakarta.Jembatan.

[2] Al-Quran dan terjemahnya.1976. Semarang.PT Tanjung Masa Inti.

[3] Al-ghozali.tanpa tahun.Cainta dan Bahagia.Tanpa penerjemah.1987. Jakarta.Tinta Emas

[4] Al-ghozali.tanpa tahun.Rahasia Keajaiban Hati. (terjemahan oleh Immun El B) .tanpa penerjemah.1987.Surabaya. PT Al-Ikhlas.

[5] Geertz,H.1985.Keluarga Jawa.PT Temprint.

[6] Ismail,M. Tanpa Tahun.Bunga Rampai PEmikiran Islam. Terjemahan oleh Nurkholis.1995. Jakarta.GIP

[7] Iwan, G.1994.Buku Pintar.Jakarta. 